\title{
INFLUENCE OF FERTILIZER AND HYDROGEL ON PHYSICAL- CHEMICAL ATTRIBUTES OF SUBSTRATE FOR SEEDLING PRODUCTION
}

\author{
INFLUÊNCIA DE ADUBAÇÃO E HIDROGEL NOS ATRIBUTOS FÍSICO-QUÍMICOS \\ DE SUBSTRATO PARA PRODUÇÃO DE MUDAS FLORESTAIS
}

\author{
Glauce Taís de Oliveira Sousa AZEVEDO'; Anderson Marcos de SOUZA²; Gileno Brito de \\ AZEVEDO $^{2}$; Paulo Eduardo TEODORO' ${ }^{1}$; José Raimundo Luduvico de SOUSA ${ }^{1}$ \\ 1. Universidade Federal de Mato Grosso do Sul, Campus de Chapadão do Sul, Chapadão do Sul, MS, Brasil. glauce.azevedo@ufms.br; \\ 2. Universidade de Brasília, Campus Darcy Ribeiro, Faculdade de Tecnologia, Departamento de Engenharia Florestal, Brasília, DF, \\ Brasil.
}

\begin{abstract}
The incorporation of the hydrogel into the substrate used in the forest nursery promotes improvements in its physical-chemical attributes. However, several factors influence the hydrogel efficiency, such as the increase of salts, promoted by fertilizer of the substrate. Therefore, this study aimed to evaluate the effects of the incorporation of fertilizer levels and hydrogel doses on the physical-chemical attributes of a substrate to produce forest seedlings. Different levels of basic fertilizer commonly used in the nursery (100\%, $50 \%$ and $0 \%)$ and different doses of the hydrogel $\left(0,1,2\right.$ and $\left.3 \mathrm{~g} \mathrm{~L}^{-1}\right)$ were incorporated into the substrate Tropstrato Florestal ${ }^{\circledR}$, consisting of 12 treatments in a $3 \times 4$ factorial scheme. A sample of the substrate in each treatment was sent for analysis of its physical and chemical attributes. To evaluate the effect of the treatments on the physical-chemical attributes of the substrate, was used the multivariate principal components analyses. The levels of fertilizer and hydrogel doses were correlated with the attributes of the substrates obtained in each treatment. The incorporation of different fertilizer levels and hydrogel doses to the substrate modified their chemical and physical attributes. Fertilizers have influenced mainly the chemical attributes of the substrate, whereas hydrogels have influenced the physical attributes, mainly those related to water retention capacity and availability.
\end{abstract}

KEYWORDS: Water-retaining polymer. Forest nursery. Water retention.

\section{INTRODUCTION}

The seedling production aims to obtain quality seedlings for the different purposes, such as commercial plantations, recovery of degraded areas or urban afforestation. These, besides resisting adverse field conditions, should be able to develop and externalize all their growth potential (MORGADO et al., 2000; WENDLING; DUTRA, 2010).

There are several cultural techniques that alter seedlings' quality. Among these, there is the use of substrates with favorable characteristics for their development. In addition to the sustentation, a suitable substrate should allow a good supply of oxygen, water and nutrients for the development of seedlings (HARTMANN et al., 2011). To ensure adequate quality substrates for plant growth, it is essential to characterize the physical, chemical and biological attributes of these materials (ABREU et al., 2007).

Among the chemical attributes, highlight the electrical conductivity and $\mathrm{pH}$ of the substrate solution, whom directly affect the availability of nutrients to plants (KÄMPF, 2005; LUDWIG;
GUERRERO; FERNANDES, 2014). Physical attributes, represented by density, porosity, particle size and space occupied by air and water (KÄMPF, 2005), are decisive in the substrate choosing, because they are not susceptible to modification after the beginning of the production process (VERDONCK; PENNINCK; DE BOODT, 1984). It is important to highlight that the adequate values for these attributes depend on the intrinsic needs of each species and on the management adopted in each nursery.

Thus, it may be necessary to adapt a substrate by incorporating materials with desirable chemical, physical, biological and economic characteristics (DANNER et al., 2007). Among these, the incorporation of hydrogel to the substrate used in the nursery has presented promising results in the quality of forest seedlings (MALDONADOBENITEZ et al., 2011; BERNARDI et al., 2012; LIU et al., 2013; ORIKIRIZA et al., 2013; AZEVEDO et al., 2015, 2016; MEWS et al., 2015; NAVROSKI et al., 2015a, 2015b, 2016c).

Also known as water-retaining polymers, hydrogels are reticulated macromolecules with segments of hydrophilic groups which can absorb 
and retain liquids, having different compositions (BAI et al., 2010; LANDIS; HAASE, 2012; MILANI et al., 2017; MONTEIRO NETO et al., 2017). In agriculture, the most commonly used hydrogel is polyacrylamide-based, and has the ability to absorb and to store a hundred times its weight in water, releasing it gradually to the plants (ABEDI-KOUPAI; ASADKAZEMI, 2006; LANDIS; HAASE, 2012; HAN et al., 2013; MILANI et al., 2017; MONTEIRO NETO et al., 2017).

The incorporation of the hydrogel to the substrate improves its physical and chemical attributes, mostly in aeration and water retention and availability (BAI et al., 2010; NARJARY et al., 2012; JAMNICKÁ et al., 2013; NAVROSKI et al., 2015a, 2016b; EL-ASMAR et al., 2017). However, hydrogel efficiency may vary depending on factors such as: substrate characteristics, hydrogel dose and salts amounts present in the medium (ABEDIKOUPAI; ASADKAZEMI, 2006; LANDIS; HAASE, 2012; AZEVEDO et al., 2015, 2016; YU et al., 2017). The increase of salts, promoted by inclusion of fertilizer to the substrate, may reduce hydrogel effects on substrate attributes (ABEDIKOUPAI; ASADKAZEMI, 2006; LANDIS; HAASE, 2012).

Therefore, this study aimed to evaluate the incorporation effects of fertilizer levels and hydrogel doses on substrates' physical and chemical attributes for the producing forest seedlings.

\section{MATERIAL AND METHODS}

The experiment was carried out in the forest nursery of the company Paisagem Nativa, located in Planaltina - DF, on highway DF 230, Km 4,5, at coordinates $16^{\circ} 12^{\prime} 31$ "S; 48 $44^{\prime} 26^{\prime \prime W}$. The nursery is intended to produce native and exotic forest species seedlings, in containers of various sizes and ways of management. The commercial substrate Tropstrato Florestal® was used for the experiment. Different levels of base fertilizer commonly used in the nursery and different doses and hydrogel doses were incorporated into the substrate, consisting of 12 treatments in $3 \times 4$ factorial arrangement (three fertilizer levels and four hydrogel doses).

The base fertilizer commonly used in the nursery, as determined by the experience of the nurseryman, is composed of: $1.5 \mathrm{~kg}$ of Forthcote $\AA$ (slow-release fertilizer 15-9-12); $2.0 \mathrm{~kg}$ of single superphosphate with yoorin; $4.0 \mathrm{~kg}$ of organic compound (chicken manure), for every $200 \mathrm{~kg}$ of substrate. This composition was regarded as $100 \%$ of fertilizer level, being also used levels of $50 \%$ (half of the fertilizer commonly used in the nursery) and $0 \%$ (without fertilizer). The hydrogel doses used were $0,1,2$ and $3 \mathrm{~g} \mathrm{~L}^{-1}$ substrate, incorporated into the substrate in its dehydrated form. These were defined according to Azevedo et al. (2015). These authors found that doses greater than $4 \mathrm{~g} \mathrm{~L}^{-1}$ expel the substrate from the container, with the hydrogel expansion.

For each treatment, the fertilizer and the hydrogel were homogenized to the substrate. Thereafter, samples were taken from the substrates, which were homogenized, forming a single sample per treatment. These were sent for analysis of their physical and chemical attributes. The attributes evaluated were: wet density (WD), in $\mathrm{kg} \mathrm{m}^{-3}$; dry density (DD), in $\mathrm{kg} \mathrm{m}^{-3}$; total porosity (TP), in \%; aeration space (AS), in \%; readily available water (RAW), in \%; water buffering capacity (WBC), in $\%$; remaining water $(\mathrm{RW})$, in \%; water holding capacity at 10 and $50 \mathrm{~cm}$ (WHC 10 and WHC 50), in $\%$; hydrogenionic potential $(\mathrm{pH})$; electrical conductivity (EC), in $\mathrm{mS} \mathrm{cm}^{-1}$.

The analyzes were carried out at the Laboratory of Substrates belonging to the Department of Horticulture and Forestry of the Federal University of Rio Grande do Sul, Brazil, in accordance with the Normative Instruction No. 17 of the Ministry of Agriculture, Livestock and Food Supply (FERMINO, 2003; MAPA, 2007).

To evaluate the effect of the treatments on the substrates' physical and chemical attributes, it was used the multivariate of Principal Components Analysis (PCA), considering the standardized data. The basic objective of PCA is to obtain latent variables representing linear combinations of a group of variables under study which are, in turn, correlated (CHATFIELD; COLLINS, 1995; FERREIRA, 2008). Through the dispersion of considered principal components was possible to evaluate the similarity or dissimilarity of the treatments and thus, group them into defined subgroups, i.e., the most similar belonging to the same group, and the ones that are heterogeneous with each other belonging to different groups (FERREIRA, 2008; MINGOTI, 2008; LOBÃO et al., 2010).

\section{RESULTS AND DISCUSSION}

The fertilizer levels and hydrogel doses were correlated with the attributes of the substrates obtained in each treatment. The correlation of Pearson $\left|r_{i j}\right|$ among these elements was represented by correlations networks (FRUCHTERMAN; REINGOLD, 1991). In these networks, the variables 
(nodes) are connected by lines, which have thickness proportional to the absolute value of the correlation between them. The length of the lines indicates the intensity of the correlations, so that shorter lines represent stronger correlations (EPSKAMP et al., 2012). The thickness of the lines was controlled by applying a cut-off value of 0.7 , which means that only $\left|r_{i j}\right| \geq 0,7$ have their edges highlighted. Positive correlations were highlighted in green, while negative ones were represented in red. All analyzes were performed using the Rbio software (BHERING, 2017).

The incorporation of different fertilizer levels and hydrogel doses to the substrate modified their chemical and physical attributes (Table 1 and Figure $1 \mathrm{~A}$ and $1 \mathrm{~B})$. When considering the chemical attributes of the substrate, the PCA revealed that the fertilizer was the determining factor in the formation of the three treatment groups (Figure 1A). The treatments without fertilizer were grouped differently than the other treatments and positively influenced the $\mathrm{pH}$ values. The treatments composed by the fertilizer levels of $50 \%$ and $100 \%$ favored the EC. The effect of the hydrogel on this variable was verified only at its highest dose, in combination with
$100 \%$ of fertilizer, being this treatment isolated from the others. Substrates' chemical properties are directly related to the availability and absorption of nutrients by plants (BERNERT et al., 2015). These properties are easier to be managed by the nurseryman through the use of fertilizers, irrigation and fertigation (KÄMPF, 2005). While increasing fertilizer levels has allowed lowering the substrate's $\mathrm{pH}$ (Table 1 and Figure 1A), all treatments presented values within the range considered ideal for the seedlings' development, that is, from 5.5 to 6.5 (VALERI; CORRADINI, 2005).

In contrast to the chemical attributes of the substrate, the hydrogel was the determining factor in the treatments grouping regarding their physical attributes (Figure 1B). The first group was formed by the treatments without hydrogel, which favored the AS. The treatments composed of hydrogel doses of 1 and $2 \mathrm{~g} \mathrm{~L}^{-1}$, regardless of their fertilizer level, and the dose of $3 \mathrm{~g} \mathrm{~L}^{-1}$, without fertilizer, favored mainly the attributes related to water retention in the substrate (WHC10, WHC50 and RW). The treatments with $3 \mathrm{~g} \mathrm{~L}^{-1}$ hydrogel doses associated to $50 \%$ and $100 \%$ fertilizer formed a distinct group and influenced mainly the WD.

Table 1. Physical and chemical analysis of Tropstrato Florestal ${ }^{\circledR}$ substrate with incorporation of different levels of fertilizer and hydrogel doses.

\begin{tabular}{|c|c|c|c|c|c|c|c|c|c|c|c|c|}
\hline $\mathrm{FL}$ & HD & $\mathrm{pH}$ & $\mathrm{EC}$ & WD & DD & TP & AS & RAW & WBC & RW & $\mathrm{WHC}_{10}$ & $\mathrm{WHC}_{50}$ \\
\hline 0 & 0 & 5,9 & 0,5 & 434,1 & 195,2 & 89,5 & 39,8 & 18,2 & 3,0 & 28,5 & 49,7 & 31,5 \\
\hline 0 & 1 & 5,9 & 0,6 & 436,2 & 197,3 & 89,6 & 33,8 & 20,2 & 3,0 & 32,6 & 55,8 & 35,6 \\
\hline 0 & 2 & 5,9 & 0,7 & 440,2 & 195,4 & 84,7 & 32,4 & 16,5 & 0,9 & 34,9 & 52,3 & 35,9 \\
\hline 0 & 3 & 6,0 & 0,7 & 426,5 & 189,6 & 81,2 & 34,5 & 8,5 & 1,3 & 37,0 & 46,7 & 38,2 \\
\hline 50 & 0 & 5,7 & 1,1 & 459,8 & 200,3 & 90,1 & 41,1 & 17,7 & 2,7 & 28,5 & 49,0 & 31,2 \\
\hline 50 & 1 & 5,7 & 1,0 & 447,5 & 194,9 & 90,1 & 35,2 & 20,7 & 2,9 & 31,3 & 54,9 & 34,2 \\
\hline 50 & 2 & 5,7 & 1,0 & 449,4 & 193,1 & 87,4 & 33,2 & 18,0 & 1,6 & 34,5 & 54,2 & 36,2 \\
\hline 50 & 3 & 5,6 & 1,2 & 430,1 & 203,7 & 81,1 & 35,9 & 8,5 & 0,3 & 36,4 & 45,2 & 36,7 \\
\hline 100 & 0 & 5,7 & 1,2 & 442,5 & 198,0 & 90,5 & 41,0 & 17,4 & 2,9 & 29,2 & 49,5 & 32,1 \\
\hline 100 & 1 & 5,5 & 1,3 & 435,1 & 190,6 & 91,2 & 38,4 & 17,7 & 2,4 & 32,8 & 52,9 & 35,2 \\
\hline 100 & 2 & 5,5 & 1,3 & 440,1 & 195,6 & 83,5 & 33,1 & 14,5 & 0,4 & 35,6 & 50,4 & 35,9 \\
\hline 100 & 3 & 5,4 & 1,9 & 441,1 & 215,0 & 79,4 & 34,6 & 9,5 & 1,3 & 34,0 & 44,8 & 35,3 \\
\hline \multicolumn{13}{|c|}{ Average attributes for the levels of each factor } \\
\hline 0 & & 5,9 & 0,6 & 434,3 & 194,3 & 86,2 & 35,1 & 15,8 & 2,1 & 33,2 & 51,1 & 35,3 \\
\hline 50 & & 5,6 & 1,1 & 446,7 & 198,0 & 87,2 & 36,4 & 16,2 & 1,9 & 32,7 & 50,8 & 34,6 \\
\hline 100 & & 5,5 & 1,4 & 439,7 & 199,8 & 86,2 & 36,8 & 14,8 & 1,7 & 32,9 & 49,4 & 34,6 \\
\hline & 0 & 5,8 & 0,9 & 445,4 & 197,8 & 90,0 & 40,6 & 17,8 & 2,9 & 28,7 & 49,4 & 31,6 \\
\hline & 1 & 5,7 & 0,9 & 439,6 & 194,3 & 90,3 & 35,8 & 19,5 & 2,7 & 32,2 & 54,5 & 35,0 \\
\hline & 2 & 5,7 & 1,0 & 443,2 & 194,7 & 85,2 & 32,9 & 16,3 & 1,0 & 35,0 & 52,3 & 36,0 \\
\hline & 3 & 5,6 & 1,3 & 432,6 & 202,8 & 80,6 & 35,0 & 8,8 & 1,0 & 35,8 & 45,6 & 36,7 \\
\hline
\end{tabular}

$\mathrm{FL}=$ fertilizer level $(\%) ; \mathrm{HD}=$ hydrogel dose $\left(\mathrm{g} \mathrm{L}^{-1}\right) ; \mathrm{pH}=$ hydrogenionic potential; $\mathrm{EC}=$ electrical conductivity $\left(\mathrm{mS} \mathrm{cm}^{-1}\right) ; \mathrm{WD}=$ wet density $\left(\mathrm{kg} \mathrm{m}^{-3}\right) ; \mathrm{DD}=\operatorname{dry}$ density $\left(\mathrm{kg} \mathrm{m}^{-3}\right) ; \mathrm{TP}=$ total porosity $(\%)$; $\mathrm{AS}=$ aeration space $(\%)$; $\mathrm{RAW}=$ readily available water $(\%)$; $\mathrm{WBC}=$ water buffering capacity $(\%) ; \mathrm{RW}=$ remaining water $(\%) ; \mathrm{WHC}_{10}$ e $\mathrm{WHC}_{50}=$ water holding capacity at 10 and $50 \mathrm{~cm}$, respectively $(\%)$. 

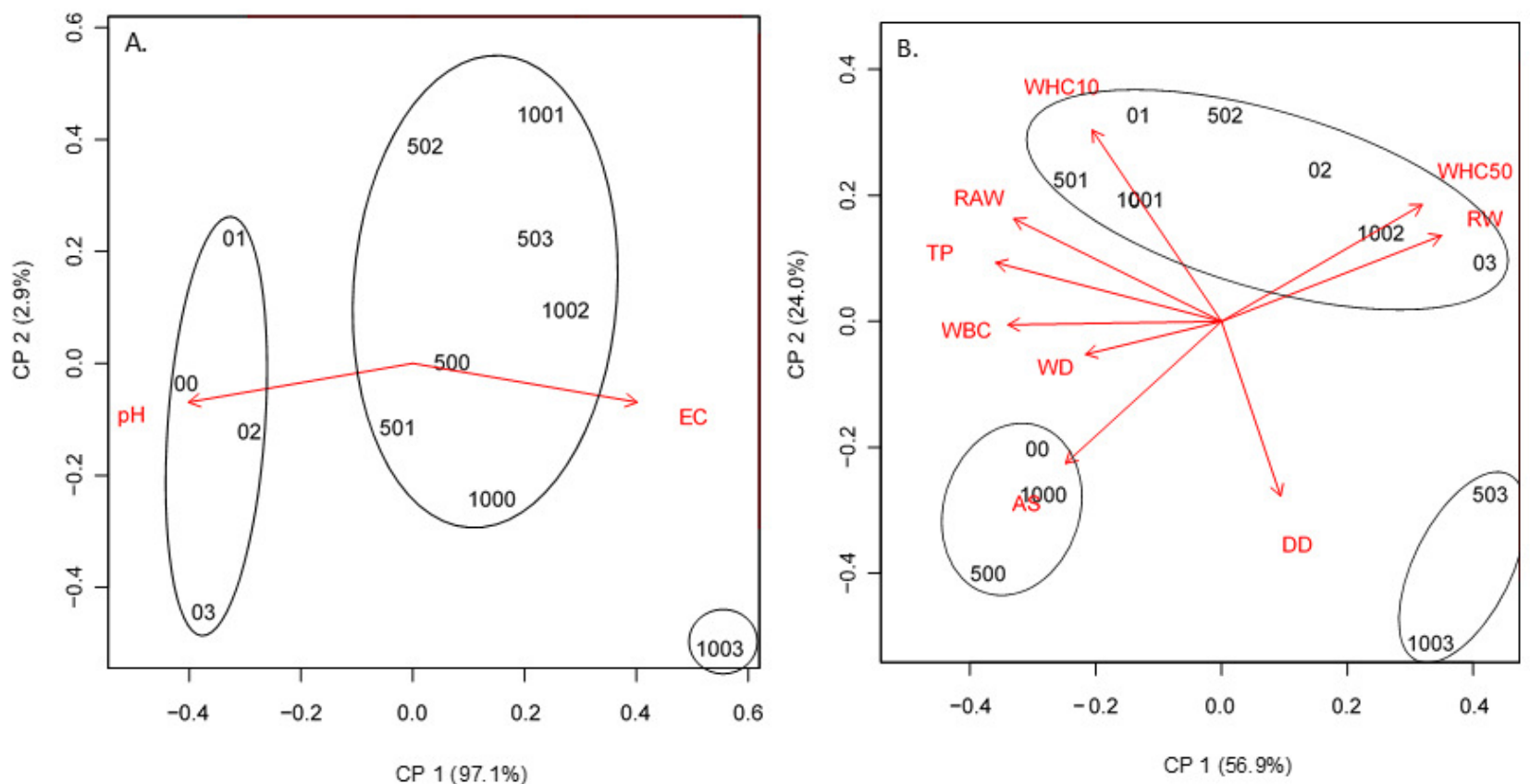

Figure 1. Ordering diagram (biplot) produced by Principal Component Analyses based on the chemical (A) and physical (B) attributes of the Tropstrato Florestal ${ }^{\circledR}$ substrate, with fertilizer levels and hydrogel doses incorporated. Numbers represent treatments, where the last digit indicates the hydrogel dose $(0,1,2$ and $\left.3 \mathrm{~g} \mathrm{~L}^{-1}\right)$ whereas the previous digits indicate the fertilizer level $(0 \%, 50 \%$ and $100 \%) \cdot \mathrm{pH}=$ hydrogenionic potential; $\mathrm{EC}=$ electrical conductivity $\left(\mathrm{mS} \mathrm{cm}^{-1}\right) ; \mathrm{WD}=$ wet density $\left(\mathrm{kg} \mathrm{m}^{-3}\right) ; \mathrm{DD}=$ dry density $\left(\mathrm{kg} \mathrm{m}^{-3}\right) ; \mathrm{TP}=$ total porosity $(\%) ; \mathrm{AS}=$ aeration space $(\%)$, RAW = readily available water $(\%) ; \mathrm{WBC}=$ water buffering capacity $(\%)$; $\mathrm{RW}=$ remaining water $(\%) ; \mathrm{WHC}_{10}$ e $\mathrm{WHC}_{50}=$ water holding capacity at 10 and $50 \mathrm{~cm}$, respectively (\%).

The non-influence of the hydrogel usage in this substrate attribute diverges from results found in the literature, which report soil's and substrate's $\mathrm{pH}$ increase (VICHIATO; VICHIATO; SILVA, 2004; NAVROSKI et al., 2015a, 2016b, 2016c) or reduction (BAI et al., 2010; SHAHID et al., 2012; FAN et al., 2015), as dose increases. The type of soil or substrate, its physical and chemical attributes and the chemical structure of the hydrogel may influence its effects on pH (BAI et al., 2010; SHAHID et al., 2012; FAN et al., 2015).

The increase of EC in the substrate by increasing the fertilizer level is mainly due to the concentration of salts caused by the fertilizer, being an indicative of the salinity of the substrate (KÄMPF, 2005). High EC levels can damage roots and root hairs, preventing water and nutrients absorption, affecting the physiological activity and favoring the incidence and severity of some pathogens (RODRIGUES, 2002). Hydrogel effects on the substrate's EC were verified only at its highest dose associated with a higher fertilizer level. In the literature, hydrogels are reported to increase the value of this attribute as increasing its doses on the substrate (BAI et al., 2010; SHAHID et al., 2012; NAVROSKI et al., 2015a, 2016b). This effect may be the result of hydrogel's chemical composition and substrate's characteristics (BAI et al., 2010; SHAHID et al., 2012).

When evaluating the correlation between fertilizer levels and hydrogel doses with the physical-chemical attributes of the substrates (Figure 2), the results obtained in the PCA were confirmed, where the fertilizer had a greater influence on the chemical attributes, while the hydrogel influenced the physical attributes. Fertilizer levels showed strong negative correlations with $\mathrm{pH}$ and positive correlation with $\mathrm{EC}$, not presenting any strong correlations with substrates' physical attributes. In its turn, hydrogel doses had strong positive correlations with RW and WHC50 and negative correlations with AS, TP, RAW and WBC.

Substrates' physical properties were influenced mainly by hydrogels doses. In the literature, several studies suggest the benefit of incorporating hydrogels into the substrates, especially in storage capacity and water availability for plants (MARTYN; SZOT, 2001; NAVROSKI et al., 2015a, 2016a, 2016b, 2016d), corroborating the results obtained in this study. It is important to highlight that, at all fertilizer levels, the greater 
RAW was obtained in the hydrogel dose of $1 \mathrm{~g} \mathrm{~L}^{-1}$. From this dose, hydrogels provided a higher water retention, but also a higher RW amount, that is, water hardly available to the plants, requiring a greater energy expenditure for the plants to take advantage of it.

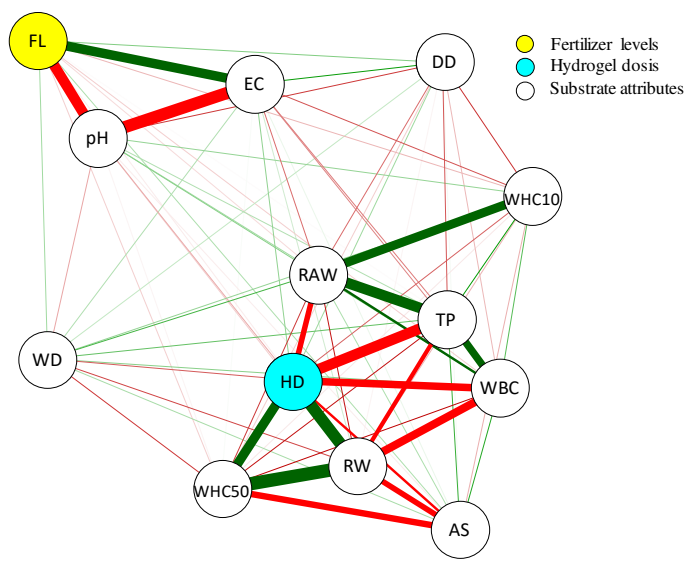

Figure 2. Correlations network between fertilizer levels, hydrogel doses and chemical and physical attributes of the Tropstrato Florestal ${ }^{\circledR}$ substrate. $\mathrm{FL}=$ fertilizer level; $\mathrm{H}=$ hydrogel dose; $\mathrm{pH}=$ hydrogenionic potential; $\mathrm{EC}=$ electrical conductivity; $\mathrm{WD}=$ wet density; $\mathrm{DD}=$ dry density; $\mathrm{TP}=$ total porosity; $\mathrm{AS}=$ aeration space; $\mathrm{RAW}=$ readily available water; $\mathrm{WBC}=$ water buffering capacity; $\mathrm{RW}=$ remaining water; $\mathrm{WHC10}$ e WHC50 = water holding capacity at 10 and $50 \mathrm{~cm}$, respectively.

Thus, hydrogels acts as a water reservoir in substrates, by retaining water at high matrix potentials, preventing or reducing percolation losses when there is a water supply that exceeds its retention capacity (OLIVEIRA et al., 2004). Corroborating with the higher retention of water in substrates, the AS values were lower in the presence of hydrogels. This was probably due to the filling of the larger pores in substrates and the expansion of hydrogels granules after their hydration, being these results similar to those obtained by other authors (NAVROSKI et al., 2015a, 2016a).

The water retention capacity of hydrogels can be influenced by several factors, such as its physical and chemical composition, particle size, texture, soil $\mathrm{pH}$ and density, as well as the soluble salts present in the environment (AKHTER et al., 2004; COELHO JUNIOR et al., 2008; LANDIS; HAASE, 2012; SHAHID et al., 2012; HAN et al., 2013). In this study, although increased fertilizer levels promoted increases in substrates' EC, these were not enough to significantly affect the water retention promoted by hydrogels, diverging from the results obtained by Azevedo et al. (2006). These authors observed that, in addition to EC of the nutrient solution, different fertilizers levels interfered in the retention capacity of the nutrient solution by hydrogels.

The usage of hydrogels in substrates of seedlings production proved to be a promising alternative for the improvement of substrate quality. Thus, the addition of hydrogel to the substrate of forest seedlings production may be indicated, since some authors have already reported gains in the productive process with the hydrogel incorporated to the substrate (AZEVEDO et al., 2015; MEWS et al., 2015; NAVROSKI et al., 2015b, 2016a; MENEGATTI et al., 2017). However, the hydrogel effect on seedling growth may vary depending on the species, production system adopted, and type of fertilizer used in the nursery. Therefore, adjustments may be necessary in the production process adopted in each forest nursery.

\section{ACKNOWLEDGEMENTS}

The authors thank the Paisagem Nativa nursery for the availability of all the necessary material for the research and CAPES for granting the doctoral scholarship to the first author.

RESUMO: A incorporação do hidrogel ao substrato utilizado no viveiro florestal promove melhorias em seus atributos físico-químicos. Porém vários fatores influenciam na eficiência do hidrogel, como o aumento de sais, promovido pela adubação do substrato. Portanto, este estudo teve como objetivo avaliar os efeitos da incorporação de níveis de adubação e doses de hidrogel sobre os atributos físico-químicos de um substrato para 
a produção de mudas florestais. Foram incorporados ao substrato Tropstrato Florestal® diferentes níveis da adubação de base comumente utilizada no viveiro (100\%, 50\% e $0 \%)$ e diferentes doses do hidrogel (0, 1,2 e 3 $\mathrm{g} \mathrm{L}^{-1}$ ), consistindo em 12 tratamentos em esquema fatorial $3 \times 4$. Uma amostra do substrato em cada tratamento foi encaminhada para análise de seus atributos físicos e químicos. Para avaliar o efeito dos tratamentos sobre os atributos físico-químicos do substrato foi utilizada a análise multivariada de componentes principais. Os níveis de adubação e doses de hidrogel foram correlacionados com os atributos dos substratos obtidos em cada tratamento. A incorporação de diferentes níveis de adubação e doses de hidrogel ao substrato modificaram seus atributos químicos e físicos. A adubação influenciou principalmente os atributos químicos do substrato, enquanto que o hidrogel os atributos físicos, principalmente os relacionados à capacidade de retenção e disponibilidade de água.

PALAVRAS-CHAVE: Polímero hidroretentor. Viveiro florestal. Retenção de água.

\section{REFERENCES}

ABEDI-KOUPAI, J.; ASADKAZEMI, J. Effects of a hydrophilic polymer on the field performande of an ornamental plant (Cupressus arizonica) under reduced irrigation regimes. Iranian Polymer Journal, v. 15, n. 9, p. 715-725, 2006.

ABREU, M. F. de; ABREU, C. A. de; SARZI, I.; PADUA JUNIOR, A. L. Extratores aquosos para a caracterização química de substratos para plantas. Horticultura Brasileira, v. 25, n. 2, p. 184-187, jun. 2007. https://doi.org/10.1590/S0102-05362007000200011

AKHTER, J.; MAHMOOD, K.; MALIK, K. A.; MARDAN, A.; AHMAD, M.; IQBAL, M. M. Effects of hydrogel amendment on water storage of sandy loam and loam soils and seedling growth of barley, wheat and chickpea. Plant Soil Environment, v. 50, n. 10, p. 463-469, 2004. https://doi.org/10.17221/4059-PSE

AZEVEDO, G. T. O. S.; AZEVEDO, G. B.; SOUZA, A. M.; MEWS, C. L.; SOUSA, J. R. L. Effect of hydrogel doses in the quality of Corymbia citriodora Hill \& Johnson Seedlings. Nativa, v. 4, n. 4, p. 244-248, 2016. https://doi.org/10.14583/2318-7670.v04n04a10

AZEVEDO, G. T. O. S.; SOUZA, A. M.; AZEVEDO, G. B.; CERQUEIRA, P. H. A. Enraizamento de miniestacas de eucalipto com diferentes doses de polímero hidroretentor incorporado ao substrato. Scientia Forestalis, v. 43, n. 108, p. 773-780, 2015. https://doi.org/10.18671/scifor.v43n108.3

AZEVEDO, T. L. F.; BERTONHA, A.; FREITAS, P. S. L.; GONÇALVES, A. C. A.; REZENDE, R.; DALLACORT, R.; BERTONHA, L. C. Retenção de soluções de sulfatos por hidrogel de poliacrilamida. Acta Scientarum Agronomy, v. 8, n. 1995, p. 287-290, 2006. https://doi.org/10.4025/actasciagron.v28i2.1131

BAI, W.; ZHANG, H.; LIU, B.; WU, Y.; SONG, J. Q. Effects of super-absorbent polymers on the physical and chemical properties of soil following different wetting and drying cycles. Soil Use and Management, v. 26 , p. 253-260, 2010. https://doi.org/10.1111/j.1475-2743.2010.00271.x

BERNARDI, M. R.; SPEROTTO JUNIOR, M.; DANIEL, O.; VITORINO, A. C. T. Crescimento de mudas de Corymbia citriodora em função do uso de hidrogel e adubação. Cerne, v. 18, n. 1, p. 67-74, 2012. https://doi.org/10.1590/S0104-77602012000100009

BERNERT, M. R.; ESCHEMBACK, V.; JADOSKI, S. O.; LIMA, A. S.; MAGGI, M. F. Características do pH e condutividade elétrica no manejo de fertirrigação. Brazilian Journal of Applied Technology for Agricultural Science, v. 8, n. 1, p. 80-87, 2015. https://doi.org/10.5935/PAeT.V8.N1.10

BHERING, L. L. Rbio : A tool for biometric and statistical analysis using the R platform. Crop Breeding and Applied Biotechnology, v. 17, p. 187-190, 2017. https://doi.org/10.1590/1984-70332017v17n2s29 
CHATFIELD, C.; COLLINS, A. J. Introduction to multivariate analysis. $7^{\text {a }}$ ed. London: Chapman \& Hall, 1995.

COELHO JUNIOR, J. B. M.; BARROS, M. F. C.; CORREA, M. M.; WANDERLEY, R. A.; COELHO

JÚNIOR, J. M.; FIGUEREDO, J. L. C. Efeito do polímero hidratassolo sobre propriedades físico-hídricas de três solos. Revista Brasileira de Ciências Agrárias, v. 3, n. 3, p. 253-259, 2008.

https://doi.org/10.5039/agraria.v3i3a238

DANNER, M. A.; CITADIN, I.; FERNANDES JUNIOR, A. de A.; ASSMANN, A. P.; MAZARO, S. M.; SASSO, S. A. Z. Formação de mudas de jabuticabeira (Plinia sp.) em diferentes substratos e tamanhos de recipientes. Revista Brasileira de Fruticultura, v. 29, n. 1, p. 179-182, abr. 2007.

https://doi.org/10.1590/S0100-29452007000100038

EL-ASMAR, J.; JAAFAR, H.; BASHOUR, I.; FARRAN, M. T.; SAOUD, I. P. Hydrogel banding improves plant growth, survival, and water use efficiency in two calcareous soils. Clean - Soil, Air, Water, v. 45, n. 7, p. 1-9, 2017. https://doi.org/10.1002/clen.201700251

EPSKAMP, S.; CRAMER, A. O. J.; WALDORP, L. J.; SCHMITTMANN, V. D.; BORSBOOM, D. qgraph : Network Visualizations of Relationships in Psychometric Data. Journal of Statistical Software, v. 48, n. 4, p. 1-18, 2012. https://doi.org/10.18637/jss.v048.i04

FAN, R.; LUO, J.; YAN, S.; ZHOU, Y.; ZHANG, Z. Effects of biochar and super absorbent polymer on substrate properties and water spinach growth. Pedosphere, v. 25, n. 5, p. 737-748, out. 2015. https://doi.org/10.1016/S1002-0160(15)30055-2

FERMINO, M. H. Métodos de análise para caracterização física de substratos. 2003. Universidade Federal do Rio Grande do Sul, 2003.

FERREIRA, D. F. Estatística Multivariada. Lavras: UFLA, 2008.

FRUCHTERMAN, T. M. J.; REINGOLD, E. M. Graph drawing by force-directed placement. Software: Practice and Experience, v. 21, n. 11, p. 1129-1164, 1991. https://doi.org/10.1002/spe.4380211102

HAN, Y.; YU, X.; YANG, P.; LI, B.; XU, L.; WANG, C. Dynamic study on water diffusivity of soil with super-absorbent polymer application. Environmental Earth Sciences, v. 69, n. 1, p. 289-296, 2013. https://doi.org/10.1007/s12665-012-1956-9

HARTMANN, H. T.; KESTER, D. E.; DAVIES, R. T.; GENEVE, R. L. Plant propagation: principles and practices. $8^{\text {a }}$ ed ed. New Jersey: Prentice Hall, 2011.

JAMNICKÁ, G.; DITMAROVÁ, L.; KURJAK, D.; KMEŤ, J.; PŠIDOVÁ, E.; MACKOVÁ, M.; GÖMÖRY, D.; STŘELCOVÁ, K. The soil hydrogel improved photosynthetic performance of beech seedlings treated under drought. Plant, Soil and Environment, v. 59, n. 10, p. 446-451, 2013. https://doi.org/10.17221/170/2013-PSE

KÄMPF, A. N. Substrato. In: KÄMPF, A. N. (Ed.). Produção comercial de plantas ornamentais. 2.ed ed. Guaíba: Agrolivros, 2005. p. 45-72.

LANDIS, T. D.; HAASE, D. L. Applications of Hydrogels in the Nursery and During Outplanting. Forest and Conservation Nursery Associations-2011, n. PMRS-P-68, p. 53-58, 2012.

LIU, F.; MA, H.; XING, S.; DU, Z.; MA, B.; JING, D. Effects of super-absorbent polymer on dry matter accumulation and nutrient uptake of Pinus pinaster container seedlings. Journal of Forest Research, v. 18, n. 3, p. 220-227, 2013. https://doi.org/10.1007/s10310-012-0340-7 
LOBÃO, M. S.; CHAGAS, M. P.; COSTA, D. D. S. P.; FERREIRA, A. T. B.; SETTE JUNIOR, C. R.; CARVALHO, I. L.; FO, M. T. Grouping of forest species by similarity of physical-anatomical characteristics and uses of wood. Cerne, v. 16, n. Suplemento, p. 97-105, 2010.

LUDWIG, F.; GUERRERO, A. C.; FERNANDES, D. M. Caracterização física e química de substratos formulados com casca de pinus e terra de subsolo. Cultivando o Saber, v. 7, n. 2, p. 152 - 162, 2014.

MALDONADO-BENITEZ, K. R.; ALDRETE, A.; LÓPEZ-UPTON, J.; VAQUERA-HUERTA, H.; CETINAALCALÁ, V. M. Producción de Pinus greggii Engelm. en mezclas de sustrato con hidrogel y riego, en vivero. Agrociencia, v. 45, n. 3, p. 389-398, 2011.

MAPA. Instrução Normativa SDA N 17. Métodos Analíticos Oficiais para Análise de Substratos para Plantas e Condicionadores de Solo. Brasília: Ministério da Agricultura, Pecuária e Abastecimento, 2007.

MARTYN, W.; SZOT, P. Influence of superabsorbents on the physical properties of horticultural substrates. International agrophysics, v. 15, p. 87-94, 2001.

MENEGATTI, D. R.; NAVROSKI, M. C.; GUOLLO, K.; FIOR, C. S.; SOUZA, A. G.; POSSENTI, J. C. Formação de mudas de guatambu em substrato com hidrogel e fertilizante de liberação controlada. Revista Espacios, v. 38, n. 22, p. 35, 2017.

MEWS, C. L.; SOUSA, J. R. L.; AZEVEDO, G. T. O. S.; SOUZA, A. M. Efeito do hidrogel e ureia na produção de mudas de Handroanthus ochraceus (Cham.) Mattos. Floresta e Ambiente, v. 22, n. 1, p. 107-116, 2015. https://doi.org/10.1590/2179-8087.080814

MILANI, P.; FRANÇA, D.; BALIEIRO, A. G.; FAEZ, R. Polymers and its applications in agriculture. Polímeros, v. 27, n. 3, p. 256-266, 2017. https://doi.org/10.1590/0104-1428.09316

MINGOTI, S. A. Análise de dados através de métodos de estatística multivariada: uma abordagem aplicada. Belo Horizonte: UFMG, 2008.

MONTEIRO NETO, J. L. L.; ARAÚJO, W. F.; CHAGAS, E. A.; DA SILVA SIQUEIRA, R. H.; OLIVEIRA, G. A.; RODRIGUEZ, C. A. Hydrogels in brazilian agriculture. Revista Agro@mbiente On-line, v. 11, n. 4, p. 347, 3 out. 2017. https://doi.org/10.18227/1982-8470ragro.v11i4.4130

MORGADO, I. F.; CARNEIRO, J. G. A.; LELES, P. S. S.; BARROSO, D. G. Nova metodologia de produção de mudas de Eucalyptus grandis W. Hill ex. Maiden utilizando resíduos prensados como substrato. Revista Árvore, v. 24, n. 1, p. 27-35, 2000.

NARJARY, B.; AGGARWAL, P.; SINGH, A.; CHAKRABORTY, D.; SINGH, R. Water availability in different soils in relation to hydrogel application. Geoderma, v. 187-188, p. 94-101, 2012.

https://doi.org/10.1016/j.geoderma.2012.03.002

NAVROSKI, M. C.; ARAÚJO, M. M.; CUNHA, F. S.; BERGHETTI, Á. L. P.; PEREIRA, M. O. Redução da adubação e melhoria das características do substrato na produção de mudas de Eucalyptus dunnii. Ciência Florestal, v. 26, n. 4, p. 1155-11-65, 2016a. https://doi.org/10.5902/1980509825106

NAVROSKI, M. C.; ARAUJO, M. M.; FIOR, C. S.; CUNHA, F. S.; BERGHETTI, Á. L. P.; PEREIRA, M. O. Uso de hidrogel possibilita redução da irrigação e melhora o crescimento inicial de mudas de Eucalyptus dunnii Maiden. Scientia Forestalis, v. 43, n. 106, p. 467-476, 2015 a.

NAVROSKI, M. C.; ARAÚJO, M. M. H.; PEREIRA, M. O.; FIOR, C. S.; DE OLIVEIRA PEREIRA, M.; FIOR, C. S. Influência do polímero hidroretentor nas características do substrato comercial para produção de mudas florestais. Interciencia, v. 41, n. 5, p. 357-361, $2016 \mathrm{~b}$. 
NAVROSKI, M. C.; ARAUJO, M. M.; REINIGER, L. R. S.; FIOR, C. S.; SCHAFER, G.; PEREIRA, M. de O. Initial growth of seedlings of Eucalyptus dunnii maiden as influenced by the addition of natural polymer and farming substrates. Revista Árvore, v. 40, n. 4, p. 627-637, 2016c. https://doi.org/10.1590/010067622016000400006

NAVROSKI, M. C.; ARAUJO, M. M.; REINIGER, L. R. S.; FIOR, C. S.; SCHAFER, G.; PEREIRA, M. O. Initial growth of seedlings of Eucalyptus dunii Maiden as influenced by the addition of natural polymer and farming substrates. Revista Árvore, v. 40, n. 4, p. 627-637, 2016d. https://doi.org/10.1590/010067622016000400006

NAVROSKI, M. C.; ARAUJO, M. M.; REINIGER, L. R. S.; MUNIZ, M. F. B.; PEREIRA, M. O.; ARAÚJO, M. M.; REININGER, L. R. S.; MUNIZ, M. F. B.; PEREIRA, M. O. Influencia do hidrogel no crescimento e no teor de nutrientes das mudas de Eucalyptus dunnii. Floresta, v. 45, n. 2, p. 315-328, $2015 \mathrm{~b}$. https://doi.org/10.5380/rf.v45i2.34411

OLIVEIRA, R. A.; REZENDE, L. S.; MARTINEZ, M. A.; MIRANDA, G. V. Influência de um polímero hidroabsorvente sobre a retenção de água no solo. Revista Brasileira de Engenharia Agrícola e Ambiental, v. 8 , n. 1, p. 160-163, 2004. https://doi.org/10.1590/S1415-43662004000100023

ORIKIRIZA, L. J. B.; AGABA, H.; EILU, G.; KABASA, J. D.; WORBES, M.; HÜTTERMANN, A. Effects of hydrogels on tree seedling performance in temperate soils before and after water stress. Journal of Environmental Protection, v. 4, n. 1, p. 713-721, 2013. https://doi.org/10.4236/jep.2013.47082

RODRIGUES, L. R. F. Técnicas de cultivo hidropônico e de controle ambiental no manejo de pragas, doenças e nutrição vegetal em ambiente protegido. Jaboticabal: FUNEP, 2002.

SHAHID, S. A.; QIDWAI, A. A.; ANWAR, F.; ULLAH, I.; RASHID, U. Improvement in the water retention characteristics of sandy loam soil using a newly synthesized poly(acrylamide-co-acrylic acid)/AlZnFe $2 \mathrm{O} 4$ superabsorbent hydrogel nanocomposite material. Molecules, v. 17, n. 8, p. 9397-9412, 2012. https://doi.org/10.3390/molecules17089397

VALERI, S. V.; CORRADINI, L. Fertilização em viveiros para produção de mudas de Eucalyptus e Pinus. In: GONÇALVES, J. L. M.; BENEDETTI, V. (Ed.). Nutrição e Fertilização Florestal. Piracicaba: IPEF, 2005. p. 167-190.

VERDONCK, O.; PENNINCK, R.; DE BOODT, M. THE PHYSICAL PROPERTIES OF DIFFERENT HORTICULTURAL SUBSTRATES. Acta Horticulturae, n. 150, p. 155-160, jun. 1984.

https://doi.org/10.17660/ActaHortic.1984.150.16

VICHIATO, M.; VICHIATO, M. R. M.; SILVA, C. R. R. Crescimento e composição mineral do porta-enxerto tangerineira cleópatra cultivado em substrato acrescido de polímero hidrorretentor. Ciência e Agrotecnologia, v. 28, n. 4, p. 748-756, ago. 2004. https://doi.org/10.1590/S1413-70542004000400004

WENDLING, I.; DUTRA, L. F. Produção de mudas de eucalipto por estaquia e miniestaquia. In: WENDLING, I.; DUTRA, L. F. (Ed.). Produção de mudas de eucalipto. Colombo: Embrapa Florestas, 2010. p. 50-60.

YU, J.; SHI, J. G.; MA, X.; DANG, P. F.; YAN, Y. L.; MAMEDOV, A. I.; SHAINBERG, I.; LEVY, G. J. Superabsorbent polymer properties and concentration effects on water retention under drying conditions. Soil Science Society of America Journal, v. 81, n. 4, p. 889-901, 2017. https://doi.org/10.2136/sssaj2016.07.0231 